\title{
THE RISK OF MULTIPLE INTRACRANIAL ANEURYSM FORMATION IN PATIENTS WITH MALIGNANT DISEASE UNDERGOING RADIATION THERAPY: A CASE REPORT AND LITERATURE REVIEW
}

\author{
Krešimir Rotim ${ }^{1-3}$, Bruno Splavski $^{1-4}$, Zlatko Trkanjec $^{5}$, Vladimir Kalousek ${ }^{6}$, \\ Ante Rotim ${ }^{7}$ and Tomislav Sajko ${ }^{1,3}$
}

${ }^{1}$ Department of Neurosurgery, Sestre milosrdnice University Hospital Centre, Zagreb, Croatia; ${ }^{2}$ Josip Juraj Strossmayer University of Osijek, Faculty of Medicine, Osijek, Croatia;

${ }^{3}$ University of Applied Health Sciences, Zagreb, Croatia;

${ }^{4}$ Josip Juraj Strossmayer University of Osijek, School of Dental Medicine and Health, Osijek, Croatia;

${ }^{5}$ Department of Neurology, Sestre milosrdnice University Hospital Centre, Zagreb, Croatia;

${ }^{6}$ Department of Radiology, Sestre milosrdnice University Hospital Centre, Zagreb, Croatia;

${ }^{7}$ Department of Neurosurgery, Dubrava University Hospital, Zagreb, Croatia

\begin{abstract}
SUMMARY - Neoplastic etiology of intracranial cerebral aneurysm is rare. Yet, the risk of its development is higher in malignant tumor patients receiving radiation therapy. Due to the possible negative effects of irradiation on intracranial vessel walls, the risk of aneurysm formation after radiation therapy, which is crucial for some types of breast cancer patients, continues to be a matter of debate. The aim of this study was to evaluate the hazard of multiple intracranial aneurysm development in patients with malignant disease undergoing radiation therapy. It is based on literature review and case report of a 77-year-old female patient who underwent surgery for multifocal invasive hormone-receptor positive ductal breast carcinoma of no special type, followed by chemotherapy, adjuvant radiation and hormone therapy. Her comorbidity included arterial hypertension and type 2 diabetes. Six unruptured intracranial aneurysms of different bilateral locations were diagnosed incidentally by multi-slice computed tomography angiography and digital subtraction angiography of cerebral vessels. Due to the bilateral aneurysm multiplicity, tumor characteristics and prognosis, comorbidity and relatively advanced age, the patient was not selected for active endovascular or microsurgical aneurysm treatment but only periodical clinical, oncologic and radiological follow-up was advised. In conclusion, the risk of multiple intracranial aneurysm formation in patients with breast cancer undergoing radiation therapy is low, but still possible. Long-term follow-up and regular cerebral angiographic check-up studies are necessary in selected malignant patients to decrease such a risk and to evade the worst outcome associated with aneurysm rupture.
\end{abstract}

Key words: Aneurysms, intracranial, multiple; Breast cancer; Radiation therapy

\section{Introduction}

Neoplastic etiology of intracranial cerebral aneurysm formation is rare ${ }^{1,2}$. Yet, some authors indicate that the risk of its development is higher in malignant tumor patients who receive radiation therapy (RT),
Correspondence to: Bruno Splavski, $M D, P h D$, Department of Neurosurgery, Sestre milosrdnice University Hospital Centre, Vinogradska c. 29, HR-10000 Zagreb, Croatia

E-mail: splavuno@gmail.com

Received February 3, 2020, accepted February 26, 2020 
particularly in those with a history of high radiation dose exposure to intracranial vessels ${ }^{3}$. However, such a risk is not always easy to define since the incidence of radiation-induced intracranial aneurysms may be affected by many different aspects ${ }^{4}$. Nonetheless, it is rather essential to note that malignancy-related death may lower the reported incidence of radiation-induced intracranial aneurysms too ${ }^{3}$.

To our knowledge, the correlation between RTtreated breast cancer and brain aneurysm is not well established. Yet, it is not clear whether postoperative irradiation in breast cancer patients increases the risk of cerebrovascular disease, although there are some reports of an enlarged stroke incidence in such patients following RT to the supraclavicular lymph nodes 5 . The interim between RT and development of possible vascular complications including vasculopathy and intracranial aneurysm formation is not strictly defined and also has to be taken in consideration ${ }^{6}$. Hence, such an interval is often long ${ }^{7}$. The risk of cerebral aneurysm formation may also be related to a higher dose of RT (in a limited field or larger exposure field). It may also depend on the mode of RT, as well as on a higher level of intracranial vessel atherosclerosis ${ }^{3}$, suggesting that elderly patients are more endangered and may have a shorter interval between RT and aneurysm appearance in comparison to younger ones ${ }^{8}$.

Asymptomatic intracranial aneurysms, including multiple ones, are being more frequently detected than before due to the increasing use of modern high-resolution imaging modalities ${ }^{9}$. Therefore, incidentally found aneurysms may be easily diagnosed even in neoplastic patients having different tumor etiology and location.

Multiple intracranial aneurysms are found in 17\%$33.2 \%$ of patients having sustained subarachnoid hemorrhage $(\mathrm{SAH})^{10}$. Although the risk factors for multiple aneurysm development are still not well known, they may be the same as for aneurysm formation in general, including high blood pressure, diabetes, smoking, stress, age, and female gender ${ }^{10-13}$, as well as vessel endothelial dysfunction. Due to the possible negative effects of irradiation on intracranial vessel walls, the risk of aneurysm formation after RT continues to be debated ${ }^{3}$.

When breast cancer is concerned, conventional prognostic factors such as tumor size, histologic type, and lymph node status and grade remain important determinants of overall survival ${ }^{14}$. The prognosis is primarily dependent on tumor molecular subtype and the three degree-of-spread categories, but generally has become rather good, with current 5-year relative survival approaching $80 \%$ of cases. Survival is longer in patients with localized disease than in those with regional spread or metastatic invasive disease at diagno$\mathrm{sis}^{15}$. RT is crucial in the management of some types of such a cancer, since it may eradicate subclinical disease and reduce recurrence rates after surgery, increasing overall surviva ${ }^{16}$. Concerning the spread of metastatic breast cancer, RT is even more important.

The aim of this study was to evaluate the risk of multiple intracranial aneurysm development in $\mathrm{pa}-$ tients with malignant disease undergoing RT. It is based on literature review and case report of female patient with six brain aneurysms, having received RT after primary breast cancer surgery to decrease metastatic spread of the disease.

\section{Case Report}

A 77-year-old female patient having undergone surgery for breast cancer followed by chemotherapy, adjuvant RT and hormone therapy was diagnosed with multiple intracranial unruptured aneurysms. Regulated arterial hypertension and non-insulin dependent type 2 diabetes were found in the patient's history. The patient was operated on due to the multifocal invasive ductal breast cancer of no special type (NST) in January 2016, when left-sided total mastectomy and evacuation of the left axillary lymph nodes were performed. The Ki-67 immunohistochemical proliferation marker was used to classify biologically distinct tumor molecular subtype, to estimate its relapse, and to investigate the potential benefits of adjuvant therapy. Because she was a node-positive patient having a high $\mathrm{Ki}-67$-labeling index $(\mathrm{Ki}-67>25 \%)$ and Luminal B subtype indicating hormone-receptor positive faster-growing tumor, she underwent cyclophosphamide-methotrexate-fluorouracil (CMF) chemotherapy and adjuvant RT following surgery. The CMF chemotherapy protocol was applied through 6 fourweek cycles during the first postoperative year (between April and August 2016). A multi-fractionated total dose of $50 \mathrm{~Gy}$ in 25 fractions was prescribed as adjuvant RT during the same year. Afterwards, she was receiving oral hormone therapy with anastrazole, 

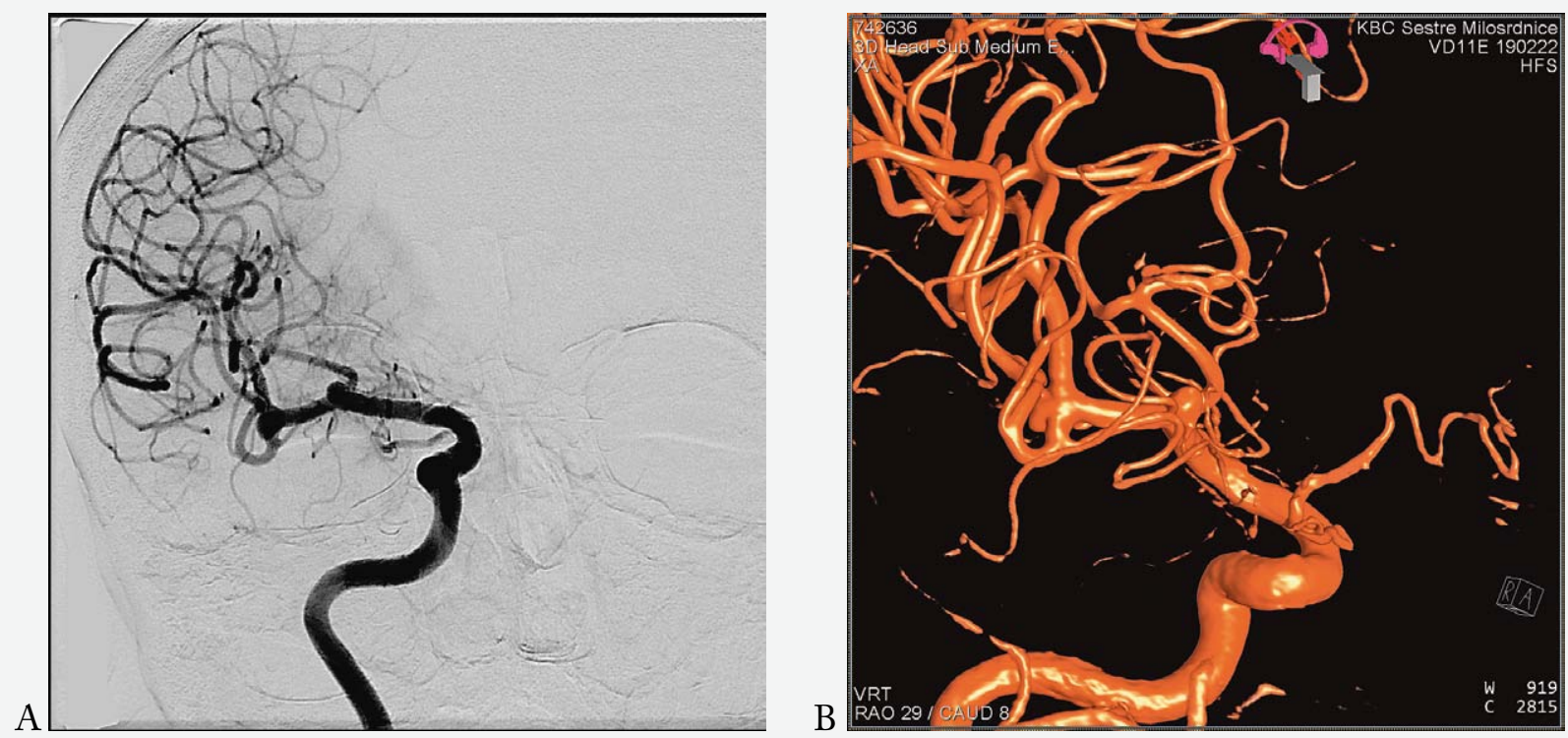

Fig. 1. (A) Supra-selective right-sided digital subtraction angiography (DSA) of the cerebral vessels revealing two aneurysms situated at $M 1$ segment and bifurcation of the right middle cerebral artery $(M C A) ;(B)$ computed tomography 3-dimensional angiography (3D CTA) confirming two aneurysms situated at M1 segment and bifurcation of the right $M C A$.
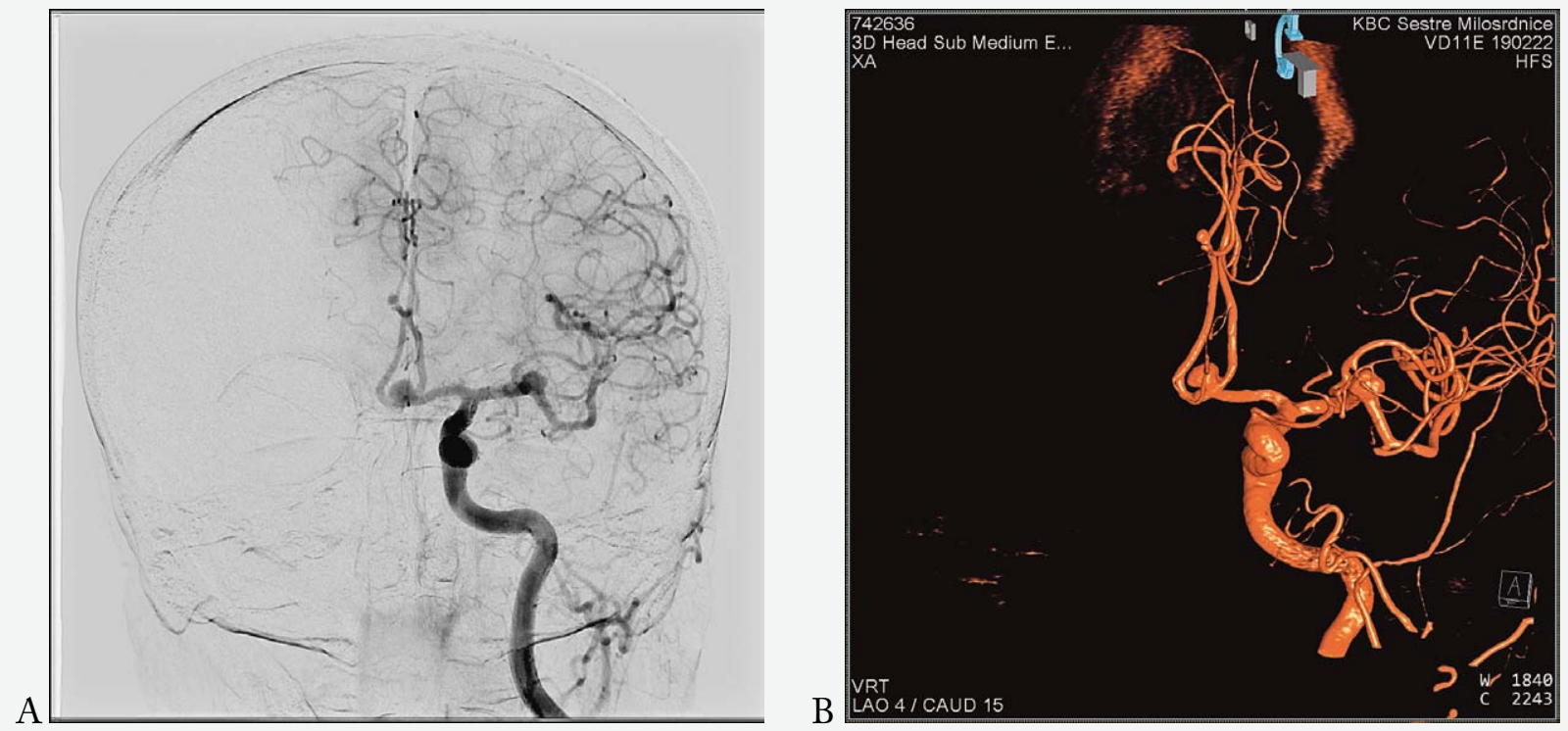

Fig. 2. (A) Supra-selective left-sided cerebral DSA revealing the left MCA bifurcation aneurysm accompanied by the anterior communicating artery (Acom) aneurysm, and additional two microaneurysms located at the left pericallosal artery; (B) computed tomography $3 D$ angiography confirming the Acom aneurysm, together with the left $M C A$ bifurcation aneurysm, and additional two microaneurysms of the left pericallosal artery.

which produces an antiestrogenic effect. On regular oncologic follow-ups, she was without radio-morphological signs of the disease relapse and/or tumor metastatic dissemination.
Following a fall due to vertigo, and brain computed tomography (CT) routine examination in January 2020, subsequently performed supra-selective digital subtraction angiography (DSA) and 3-dimensional 
CT angiography (3D CTA) of cerebral vessels revealed six intracranial aneurysms of different bilateral locations. Two of them were situated at the M1 segment and bifurcation of the right middle cerebral artery (MCA) (Fig. 1a,b). There was also the anterior communicating artery (Acom) aneurysm, along with the left MCA bifurcation aneurysm and another two microaneurysms located at the left pericallosal artery (Fig. 2a,b).

Due to the bilateral aneurysm multiplicity, tumor histopathology and molecular biology characteristics indicating faster-growing, potentially relapsing disease with relatively doubtful prognosis, comorbidity and her advanced age, the patient was not selected for active endovascular or microsurgical aneurysm treatment.

Since the average overall 5-year survival for advanced breast cancer with high proliferation markers is roughly $18 \%$ following surgery and oncologic treatment ${ }^{15}$, the conservative management together with periodical clinical, oncologic and radiological followup was advised. Follow-up magnetic resonance angiography (MRA) of the cerebral vessels was recommended as a check-up measure at one year.

\section{Discussion}

The risk of multiple intracranial aneurysm formation in patients with malignant disease undergoing $\mathrm{RT}$ is not simple to explain ${ }^{4}$, since their incidence may be affected by many different features including tumor type, histopathology and molecular biology, comorbidity, age, gender, vasculature status and adjuvant therapy received.

Tumor molecular diversity, which is a robust characteristic of breast cancer, may be responsible for tumor recurrence, and it is also important in therapeutic decision-making affecting prognosis ${ }^{17,18}$. Such a diversity demonstrates the necessity for personalized medicine in the treatment of this malignant disease, where hormone therapy for estrogen-receptor positive breast carcinoma is well-described ${ }^{19,20}$. However, despite the benefits of endocrine therapy in postmenopausal women with hormone-receptor positive breast cancer, therapy-related side effects including thromboembolic events have to be taken in consideration ${ }^{20}$. Nonetheless, this therapy may substantially reduce the risk of breast cancer recurrence ${ }^{19}$, but the risk of developing vascular disease could be presumably increased due to the suppression of protective effects of estrogen on cardiovascular system and blood vessels ${ }^{21}$. Consequently, different forms of arterial or venous vascular disease may be incited by hormone therapy for such a breast cancer. Accordingly, we speculated whether such therapy, which was prescribed to our patient on daily basis, was interconnected with multiple brain aneurysm formation.

It is also known that vascular endothelium in diabetic patients is more fragile and prone to producing atherosclerotic plaques, generating endothelial dysfunction, which together with oxidative stress additionally triggers atherogenesis ${ }^{22}$. This mechanism is more or less similar to the one responsible for aneurysm formation. Since our patient was also suffering from age-related atherosclerosis, arterial hypertension and type 2 diabetes, it seems easy to presume that some of these factors may have been involved in aneurysm formation too.

Irradiation may cause a variety of cerebrovascular injuries and hemodynamic changes affecting cerebral arterial wall. The mechanism of radiation injury to cerebral blood vessels is primarily related to phenotypic alterations in endothelium cells of the vessel wall ${ }^{23}$. Therefore, subsequent vasculopathy, inflammation and endothelial changes may also promote aneurysm growth $^{8,24,25}$, but the incidence and natural history of RT-related aneurysms can only be speculated since this issue remains rather under-reported ${ }^{4,26}$. Such aneurysms were first identified in 1984 and 1987 and described as case reports of ruptured fusiform internal carotid artery (ICA) aneurysm following RT of suprasellar germinoma in a young girl ${ }^{27}$, and basilar artery (BA) aneurysm after RT for nasopharyngeal cancer ${ }^{28}$. Considering this, it is important to underline that gamma knife stereotactic radiosurgery (SRS) may also induce brain aneurysms due to the high-dose radiation delivered to a small volume focused field ${ }^{29}$.

Taking into consideration all the above mentioned possible causes of intracranial aneurysm formation and remembering our patient's history of the disease, we believe that the main reason for this was RT, since ionizing radiation is most suitable to induce aneurysm growth and generate their multiplicity. Therefore, we are convinced that multiple aneurysms were induced by RT in our patient, although she was burdened with other possible risk factors too.

In conclusion, neoplastic cerebral aneurysms are rare but may be associated with poor outcome, which 
is mostly unrelated to the prognosis of the underlying malignant disease. The risk of multiple intracranial aneurysm formation in patients with breast cancer undergoing RT is low, but still possible. Therefore, longterm clinical follow-up and regular cerebral angiographic check-up studies are necessary for selected malignant patients having radiation dose exposure to decrease the risk of intracranial aneurysm formation, as well as to evade the worst outcome associated with possible aneurysm rupture. To support our conclusions, additional reading and systematic review of the literature are needed.

\section{References}

1. Omofoye OA, Barnett R, Lau W, Trembath D, Jordan JD, Sasaki-Adams DM. Neoplastic cerebral aneurysm from metastatic nonsmall cell lung carcinoma: case report and literature review. Neurosurgery. 2018;83(6):E221-E225. doi: 10.1093/ neuros/nyx588.

2. Zheng J, Zhang J. Neoplastic cerebral aneurysm from metastatic tumor: a systematic review of clinical and treatment characteristics. Clin Neurol Neurosurg. 2015;128:107-11. doi: 10.1016/j.clineuro.2014.11.010.

3. Yang W, Yang Y, Chen P, Wang TC, Chen KJ, Cheng CY, et al. Intracranial aneurysms formation after radiotherapy for head and neck cancer: a 10-year nationwide follow-up study. BMC Cancer. 2019;19:537. doi: org/10.1186/s12885-019-5766-2.

4. Sheehan JP, Starke RM. Aneurysm formation associated with ionizing radiation. World Neurosurg. 2014;81(3):487-9. doi: 10.1016/j.wneu.2013.11.003.

5. Nilsson G, Holmberg L, Garmo H, Terent A, Blomqvist C. Increased incidence of stroke in women with breast cancer. Eur J Cancer. 2005;41(3):423-9. doi: 10.1016/j.ejca.2004.11.013.

6. Pereira P, Cerejo A, Cruz J, Vaz R. Intracranial aneurysm and vasculopathy after surgery and radiation therapy for craniopharyngioma: case report. Neurosurgery. 2002;50(4):885-8. doi: org/10.1097/00006123-200204000-00042.

7. Cuzick J, Stewart H, Rutqvist L, Houghton J, Edwards R, Redmond C, et al. Cause-specific mortality in long-term survivors of breast cancer who participated in trials of radiotherapy. J Clin Oncol. 1994;12(3): 447-53. doi: 10.1200/jco. 1994.12.3.447.

8. Nanney AD, El Tecle NE, El Ahmadieh TY, Daou MR, Ivan $\mathrm{ENB}$, Marymont $\mathrm{MH}$, et al. Intracranial aneurysms in previously irradiated fields: literature review and case report. World Neurosurg. 2014;81(3):511-9. doi: org/10.1016/j.wneu.2013. 10.044 .

9. Ruan C, Long H, Sun H, He M, Yang K, Zhang H, et al. Endovascular coiling $v s$ s surgical clipping for unruptured intracranial aneurysm: a meta-analysis. Br J Neurosurg. 2015;29(4): 485-92. doi: 10.3109/02688697.2015.1023771.
10. Kaminogo M, Yonekura M, Shibata S. Incidence and outcome of multiple intracranial aneurysms in a defined population. Stroke. 2003;34:16-21. doi: 10.1161/01.str.0000046763.48330.ad.

11. Juvela S. Risk factors for multiple intracranial aneurysms. Stroke. 2000;31:392-7. doi: 10.1161/01.str.31.2.392

12. Østergaard JR, Hog E. Incidence of multiple intracranial aneurysms: influence of arterial hypertension and gender. J Neurosurg. 1985;63:49-55. doi: 10.3171/jns.1985.63.1.0049.

13. Qureshi AI, Suarez JI, Parekh PD, Sung G, Geocadin R, Bhardwaj A, et al. Risk factors for multiple intracranial aneurysms. Neurosurgery. 1998;43:22-7. doi: 10.1097/00006123199807000-00013.

14. Soerjomataram I, Louwman MWJ, Ribot JG, Roukema JA, Coebergh JWW. An overview of prognostic factors for longterm survivors of breast cancer. Breast Cancer Res Treat. 2008;107:309-30. doi: org/10.1007/s10549-007-9556-1.

15. Taylor R, Coates M. Breast cancer five-year survival in New South Wales women, 1972 to 1991. Aust N Z J Public Health. 1997;21(2):199-205. doi: 10.1111/j.1467-842x.1997.tb01683.x.

16. Yang TJ, Ho AY. Radiation therapy in the management of breast cancer. Surg Clin North Am. 2013;93(2):455-71. doi: 10.1016/j.suc.2013.01.002.

17. Inwald EC, Klinkhammer-Schalke M, Hofstädter F, Zeman F, Koller M, Gerstenhauer M, et al. Ki-67 is a prognostic parameter in breast cancer patients: results of a large populationbased cohort of a cancer registry. Breast Cancer Res Treat. 2013;139(2):539-52.

18. Wang Y, Yin Q, Yu Q, Zhang J, Liu Z, Wang S, et al. A retrospective study of breast cancer subtypes: the risk of relapse and the relations with treatments. Breast Cancer Res Treat. 2011; 130(2):489-98. doi: 10.1007/s10549-011-1709-6.

19. Matthews A, Stanway S, Farmer RE, Strongman H, Thomas S, Lyon AR, et al. Long term adjuvant endocrine therapy and risk of cardiovascular disease in female breast cancer survivors: systematic review. BMJ. 2018;363:k3845. doi: https://doi. org/10.1136/bmj.k3845.

20. Puhalla S, Bhattacharya S, Davidson NE. Hormonal therapy in breast cancer: a model disease for the personalization of cancer care. Mol Oncol. 2012;6(2):222-36. doi: 10.1016/j.molonc. 2012.02.003.

21. Mendelsohn ME. Protective effects of estrogen on the cardiovascular system. Am J Cardiol. 2002;89(12A):12E-7E. doi: 10.1016/s0002-9149(02)02405-0.

22. Xu RS. Pathogenesis of diabetic cerebral vascular disease complication. World J Diabetes. 2015;6(1):54-66. doi: 10.4239/ wjd.v6.i1.54.

23. O'Connor MM, Mayberg MR. Effects of radiation on cerebral vasculature: a review. Neurosurgery. 2000;46(1):138-51. doi: 10.1093/neurosurgery/46.1.138.

24. Casey AT, Marsh HT, Uttley D. Intracranial aneurysm formation following radiotherapy. Br J Neurosurg. 1993;7(5):575-9. doi: org/10.3109/02688699308995083.

25. Scodary D, Tew J, Thomas G, Tomsick T, Liwnicz B. Radiation-induced cerebral aneurysms. Acta Neurochir (Wien). 1990;102(3):141-4. doi: 10.1007/BF01405429. 
26. Abla AA, Lawton MT, McDermott MW. Intracranial aneurysm formation following radiation. World Neurosurg. 2014; 81(3):492-3. doi: 10.1016/j.wneu.2014.01.007.

27. Azzarelli B, Moore J, Gilmor R, Muller J, Edwards M, Mealey J. Multiple fusiform intracranial aneurysms following curative radiation therapy for suprasellar germinoma. Case report. J Neurosurg. 1984;61(6):1141-5. doi: 10.3171/jns.1984.61.6.1141.
28. Gomori JM, Levy P, Weshler Z. Radiation-induced aneurysm of the basilar artery - a case report. Angiology. 1987;38(2 Pt 1):147-50. doi: 10.1177/000331978703800209.

29. Park KY, Ahn JY, Lee JW, Chang JH, Huh SK. De novo intracranial aneurysm formation after gamma knife radiosurgery for vestibular schwannoma. J Neurosurg. 2009;110:540-2. doi: 10.3171/2008.9.JNS08860.

Sažetak

\section{RIZIK NASTANKA VIŠESTRUKIH INTRAKRANIJSKIH ANEURIZMI U IRADIJACIJSKI LIJEČENIH BOLESNIKA S MALIGNOM BOLEŠĆU: PRIKAZ SLUČAJA I PREGLED LITERATURE}

\section{K. Rotim, B. Splavski, Z. Trkanjec, V. Kalousek, A. Rotim i T. Sajko}

Neoplastička etiologija intrakranijskih aneurizmi je rijetka. Unatoč tomu, rizik za njihov nastanak povećan je u bolesnika s malignim tumorima koji primaju iradijacijsku terapiju. Poslijeoperacijska iradijacija ključna je u liječenju pojedinih tipova karcinoma dojke, ali može imati negativan učinak na stijenku intrakranijskih krvnih žila povećavajući rizik nastanka cerebralnih aneurizmi nakon provedenog zračenja, što je stalni predmet rasprave. Cilj je ovoga rada bio prosuditi rizik nastanka višestrukih intrakranijskih aneurizmi u bolesnice kod koje je provedeno zračenje u svrhu nastavka liječenja maligne bolesti. Rad je temeljen na pregledu literature i prikazu slučaja bolesnice u dobi od 77 godina s tumorom dojke koja je operirana zbog nespecifičnog tipa multifokalnog, invazivnog, hormonski aktivnog duktalnog karcinoma nakon čega su provedeni kemoterapija, zračenje i hormonska terapija. Bolesnica se je također liječila od arterijske hipertenzije i dijabetesa tipa 2. U bolesnice je pomoću višeslojne kompjutorske tomografske angiografije i digitalne subtrakcijske angiografije moždanih krvnih žila dijagnosticirano šest nerupturiranih intrakranijskih aneurizmi obostrane lokalizacije. Uzimajući u obzir smještaj višestrukiih aneurizmi, kao i osobite značajke tumora i prognozu maligne bolesti te komorbiditet i relativno visoku životnu dob, u bolesnice nije provedeno aktivno endovaskularno ili mikrokirurško liječenje nerupturiranih aneurizmi, nego je preporučeno redovito kliničko, onkološko i radiološko praćenje. Zaključujemo kako je rizik nastanka višestrukih intrakranijskih aneurizmi u bolesnica s karcinomom dojke podvrgnutih iradijacijskom liječenju relativno malen, ali ipak moguć. Stoga su dugotrajno kliničko praćenje i redovita angiografska dijagnostička provjera nužni u selekcioniranih bolesnika kako bi se ovaj rizik umanjio i kako bi se spriječio nepovoljan ishod liječenja nastao uslijed moguće rupture cerebralne aneurizme.

Ključne riječi: Aneurizme, intrakranijske, višestruke; Karcinom dojke; Iradijacijsko liječenje 